\title{
Ardennite-bearing mineral association related to sulfide-free ores with chalcophile metals at Nežilovo, Pelagonian Massif, North Macedonia
}

\author{
Marko Bermanec $^{1}$, Nikita V. Chukanov ${ }^{2}$, Ivan Boev ${ }^{3}$, Božidar Darko Šturman ${ }^{4,+}$, Vladimir Zebec ${ }^{5}$, and \\ Vladimir Bermanec ${ }^{6}$ \\ ${ }^{1}$ Faculty of Science, University of Zagreb, HR - 10000 Zagreb, Republic of Croatia \\ ${ }^{2}$ Institute of Problems of Chemical Physics, Russian Academy of Sciences, \\ Chernogolovka, Moscow region, 142432, Russia \\ ${ }^{3}$ Faculty of Natural and Technical Sciences, Goce Delčev University, Štip, 2000, Republic of North Macedonia \\ ${ }^{4}$ Department of Mineralogy and Geology, Royal Ontario Museum, 100 Queen's Park, Toronto, Ontario, Canada \\ ${ }^{5}$ Natural History Museum, Demetrova 1, HR - 10000 Zagreb, Republic of Croatia \\ ${ }^{6}$ Faculty of Metallurgy, University of Zagreb, Aleja narodnih heroja 3, HR - 44000 Sisak, Republic of Croatia \\ $\boldsymbol{t}_{\text {deceased }}$
}

Correspondence: Marko Bermanec (marko.bermanec@gmail.com)

Received: 16 February 2021 - Revised: 10 June 2021 - Accepted: 24 June 2021 - Published: 3 August 2021

\begin{abstract}
Among numerous minerals determined at Nežilovo, Pelagonian Massif, North Macedonia, ardennite-(As) has been discovered in two different associations and studied by means of optical microscopy, electron microprobe analysis (EMPA), and single-crystal and powder Xray diffraction methods. The refractive indices of ardennite-(As) from Nežilovo are $\alpha=1.537(2)$, $\beta=1.579(1)$ and $\gamma=1.741(1)$, where $\gamma$ corresponds to the $c$ direction. The optical axial angle is $2 V_{x}=49(1)^{\circ}$. EMPA of the investigated samples yields the following empirical formulae: $\left[\mathrm{Mn}_{3.27}^{2+} \mathrm{Ca}_{0.73}\right]_{\Sigma 4.00}\left[\mathrm{Al}_{4.18} \mathrm{Mg}_{1.24} \mathrm{Fe}_{0.29} \mathrm{Mn}_{0.19}^{3+} \mathrm{Zn}_{0.10}\right]_{\Sigma 6.00}\left(\mathrm{Si}_{4.73} \mathrm{Al}_{0.27}\right)_{\Sigma 5.00}\left(\mathrm{As}_{0.96} \mathrm{Si}_{0.03} \mathrm{~V}_{0.01}\right)_{\Sigma 1.00} \mathrm{O}_{22}$

$\left[\mathrm{OH}_{5.36}\left(\mathrm{H}_{2} \mathrm{O}\right)_{0.64}\right]_{\Sigma 6.00}$ for ardennite-(As) and $\left(\mathrm{K}_{0.95} \mathrm{Na}_{0.04} \mathrm{Ba}_{0.02}\right)_{\Sigma 1.01}\left(\mathrm{Al}_{1.44} \mathrm{Fe}_{0.30}^{3+} \mathrm{Mg}_{0.20} \mathrm{Mn}_{0.03} \mathrm{Ti}_{0.02}\right.$ $\left.\mathrm{Zn}_{0.01}\right)_{\Sigma 2.00}\left(\mathrm{Si}_{3.21} \mathrm{Al}_{0.79} \mathrm{O}_{10}\right)\left(\mathrm{OH}_{1.97} \mathrm{O}_{0.03}\right)_{\Sigma 2.00}$ for the associated red mica. The unit cell parameters of ardennite-(As) determined by X-ray powder diffraction are $a=8.757(2) \AA, b=5.836(2) \AA, c=18.578(2) \AA$ and $V=941.97 \AA^{3}$. The unit cell parameters of ardennite-(As) were also determined by single-crystal X-ray diffraction and are $a=8.760(1) \AA, b=5.838(1) \AA, c=18.582(2) \AA$ and $V=950.30 \AA^{3}$.

Regularities of isomorphism in ardennite-related minerals are discussed. The presence of ardennite-(As) in association with $2 M_{1}$ and $3 T$ phengite polytypes provides evidence for three separate stages of formation. Conditions at which ardennite-(As) crystallized have been estimated based on compositional features of associated micas.
\end{abstract}

\section{Introduction}

Ore occurrences at the village of Nežilovo, Pelagonian Massif, North Macedonia, attract the attention of geologists and mineralogists because of the unusual associations of numerous rare and new oxygen-bearing minerals of chalcophile elements $(\mathrm{Pb}, \mathrm{Zn}, \mathrm{Sb}, \mathrm{Cu}, \mathrm{As})$. The uniqueness of the forma- tion hosting these occurrences (called "mixed series") is a result of complex multistage metamorphism and metasomatic transformations of different sediments with very diverse and peculiar chemical composition (see Stojanov, 1960, 19671968; Majer and Mason, 1983; Arsovski and Dumurdzhanov, 1984). An extensive description of the metamorphic conditions in the Pelagonides has been given by Most (2003). 
He was able to distinguish five different tectonometamorphic events related to Alpine orogeny based on the results of $\mathrm{K}-$ $\mathrm{Ar}, \mathrm{Ar}-\mathrm{Ar}$ and $\mathrm{Rb}-\mathrm{Sr}$ geochronology.

A large number of scientific papers have been published on the curious mineralogy of Nežilovo, including descriptions of five new mineral species, piemontite- $(\mathrm{Pb}) \quad(\mathrm{CaPb})\left(\mathrm{Al}_{2} \mathrm{Mn}^{3+}\right)\left(\mathrm{Si}_{2} \mathrm{O}_{7}\right)\left(\mathrm{SiO}_{4}\right) \mathrm{O}(\mathrm{OH})$ (Bermanec et al., 1994; Chukanov et al., 2012), nežilovite $\mathrm{PbZn}_{2} \mathrm{Mn}_{2}^{4+} \mathrm{Fe}_{8}^{3+} \mathrm{O}_{19}$ (Bermanec et al., 1996), zincohögbomite-2N6S $(\mathrm{Zn}, \mathrm{Al})_{7}\left(\mathrm{Al}, \mathrm{Fe}^{3+}, \mathrm{Ti}, \mathrm{Mg}\right)_{16} \mathrm{O}_{31}(\mathrm{OH})$ (Armbruster et al., 1998), ferricoronadite $\mathrm{Pb}\left(\mathrm{Mn}_{6}^{4+} \mathrm{Fe}_{2}^{3+}\right) \mathrm{O}_{16}$ (Chukanov et al., 2016) and zincovelesite-6N6S $\mathrm{Zn}_{3}\left(\mathrm{Fe}^{3+}, \mathrm{Mn}^{3+}, \mathrm{Al}, \mathrm{Ti}\right)_{8} \mathrm{O}_{15}(\mathrm{OH})$ (Chukanov et al., 2018b), as well as data on isomorphism, parageneses and possible mechanisms of formation of numerous rare minerals, including several tens of potentially new mineral species belonging to the epidote, högbomite and pyrochlore supergroups and magnetoplumbite, crichtonite and ilmenite groups (Barić, 1960; Barić and Ivanov, 1960; Jančev, 1975, 1998; Ivanov and Jančev, 1976; Holtstam and Langhof, 1999; Jančev and Chukanov, 2008; Chukanov et al., 2015, 2018a, b, 2019, 2020a, b; Jančev et al., 2016; Ermolaeva et al., 2016, 2017, 2019a, b; Varlamov et al., 2018).

Ardenite-(As) $\quad \mathrm{Mn}_{4}^{2+} \mathrm{Al}_{4}(\mathrm{AlMg})\left(\mathrm{AsO}_{4}\right)\left(\mathrm{SiO}_{4}\right)_{2}\left(\mathrm{Si}_{3} \mathrm{O}_{10}\right)$ $(\mathrm{OH})_{6}$ has been identified in this region, among the numerous unusual minerals, but since its initial discovery, ardennite has presented an intriguing and complex problem with the calculation of its crystal-chemical formula based on electron microprobe analyses (EMPAs) and with the taxonomy and nomenclature of ardennite-related minerals (see Pasero and Reinecke, 1991; Pasero et al., 1994; Nagashima and Armbruster, 2010; Orlandi et al., 2013). Recent discoveries of new occurrences of ardennite-(As) and related new mineral species have made it possible to obtain additional information on the regularities of isomorphism in this group of minerals.

This paper describes a new locality of ardennite-(As) in the Pelagonian Massif, North Macedonia, and discusses solid solution series between ardennite-(As) and structurally related minerals. The occurrences of ardennite-(As) in two different associations coupled with the analysis of associated mica allow the discussion of the metamorphic conditions for the formation and evolution of the Pelagonian Massif metamorphic complex. Furthermore, the problematic nomenclature of the ardennite group of minerals is discussed.

\section{Ardennite and related minerals - historical background}

Ardennite was first discovered in the Ardennes in Belgium and was named after them (von Lasaulx, 1872). It is interesting to note that when first discovered, ardennite was considered a vanadate silicoaluminate which, in accordance with the current nomenclature, could correspond to ardennite-
(V), $\mathrm{Mn}_{4}^{2+} \mathrm{Al}_{4}(\mathrm{AlMg})\left(\mathrm{VO}_{4}\right)\left(\mathrm{SiO}_{4}\right)_{2}\left(\mathrm{Si}_{3} \mathrm{O}_{10}\right)(\mathrm{OH})_{6}$. Thereafter, Pisani (1873) described a related new mineral containing arsenic. The author of this publication was convinced that it was a new mineral, different from ardennite, and claimed the priority rights of describing a new mineral species, named "dewalquite". The dispute resulted in the conclusion that arsenic and vanadium play the same role in the structure; it was decided that the name ardennite should be applied to both investigated samples because it has priority, and the name "dewalquite" was abandoned. Based on morphological and chemical similarity between ardennite and epidote, it was supposed that there is a structural similarity between these minerals (Strunz, 1935). Later on, Moore (1965) determined the space group of ardennite to be Pnmm on the basis of the powder X-ray diffraction pattern and noticed similarities between ardennite and orientite $\mathrm{Ca}_{8} \mathrm{Mn}_{10}^{3+}\left(\mathrm{SiO}_{4}\right)_{3}\left(\mathrm{Si}_{3} \mathrm{O}_{10}\right)_{3}(\mathrm{OH})_{10} \cdot 4 \mathrm{H}_{2} \mathrm{O}$. In his dissertation, Nayak (1967) described ardennite from Kajlidongri, India, including detailed optical characteristics, chemical data, differential thermal analysis and powder X-ray diffraction data of this mineral.

The crystal structure of ardennite was first determined by Donnay and Allmann (1968), who revealed some structural elements which are similar in ardennite and pumpellyite. However, the position of hydrogen was determined in their next paper (Allmann and Donnay, 1971).

A detailed description of the occurrence of ardennite from the island of Andros in Greece is given by Reinecke and Hatzipanagiotou (1987). In addition to the field description of the locality, paragenesis, rarely described in such detail, can be found in this paper, as well as the optical properties and X-ray diffraction data and discussion about the distribution of different cations over crystallochemical positions.

HRTEM and SAED analysis of ardennite samples from the island of Evvia in Greece were interpreted as a regular alternation of ardennite and another hypothetical module which gave a doubled periodicity of $37 \AA$ along the $c$ axis. These samples were extremely rich in $\mathrm{Si}$ and had a $\mathrm{Si} / \mathrm{As}$ ratio at the T4 site of almost 9:1 (Pasero and Reinecke, 1991). A high Si content was also found in an ardennite-related phase from Punta Gensane, Viù Valley, Piedmont, Italy (Chimenti, 2004). This phase was later described as a new mineral, lavoisierite $\mathrm{Mn}_{8}^{2+}\left[\mathrm{Al}_{10}\left(\mathrm{Mn}^{3+} \mathrm{Mg}\right)\right]\left[\mathrm{Si}_{11} \mathrm{P}\right] \mathrm{O}_{44}(\mathrm{OH})_{12}$ (Orlandi et al., 2013). These papers opened a discussion about the existence of other potential end-members of the ardennite group such as "ardennite-(Si)" and "ardennite-(P)". However, until now these end-members have not been found in nature. Von Walter et al. (2018) use the name "ardennite(Si)", not approved by the IMA CNMNC, to describe a mineral from Austria; however no proper chemical analysis was provided to prove the existence of this phase.

In the 2000s, the vanadate analogue of ardennite-(As) was finally discovered in nature and described by Barresi et al. (2007). In addition, in accordance with the IMA redefinition, ardennite was divided into two mineral species: 
more common ardennite-(As) and less common ardennite(V) (Barresi et al., 2007). However, this was not the first analytical confirmation of the existence of the vanadate analogue of ardennite which had been described 20 years earlier by Matsubara and Kato (1987).

The crystal structure refinement and the site occupancies of ardennite have been discussed by $\mathrm{Na}-$ gashima and Armbruster (2010). They proposed a new procedure to construct the chemical formulae of ardennite, tiragalloite $\mathrm{Mn}_{4}^{2+}\left[\mathrm{Si}_{3} \mathrm{As}^{5+} \mathrm{O}_{12}(\mathrm{OH})\right]$ and medaite $\mathrm{Mn}_{6}^{2+}\left[\mathrm{Si}_{5} \mathrm{~V}^{5+} \mathrm{O}_{18}(\mathrm{OH})\right]$. The authors also positioned the hydrogen atom differently than Pasero et al. (1994).

Alpeite $\mathrm{Ca}_{4} \mathrm{Mn}_{2}^{3+} \mathrm{Al}_{2}\left(\mathrm{Mn}^{3+} \mathrm{Mg}\right)\left(\mathrm{SiO}_{4}\right)_{2}\left(\mathrm{Si}_{3} \mathrm{O}_{10}\right)\left(\mathrm{V}^{5+} \mathrm{O}_{4}\right)$ $(\mathrm{OH})_{6}$ was also described as a member of the ardennite group (Kampf et al., 2017). While the other members of the group have aluminum as the dominant cation at both $M 1$ and $M 3$ sites, $\mathrm{Mn}^{3+}$ is the dominant cation at these sites in alpeite. Kannanite was described as the $\mathrm{Ca}$ analogue of ardennite-(V) with the $A$ site occupied by $\mathrm{Ca}$ instead of $\mathrm{Mn}^{2+}$. Kannanite and alpeite have calcium as the dominant cation at this site, while the other members of the group are ${ }^{A} \mathrm{Mn}^{2+}$-dominant. The description of alpeite and kannanite provided further understanding of the crystal-chemical diversity of the ardennite group. All these data, together with the work of Nagashima and Armbruster (2010) provided sufficient data on the possible site occupancies in ardennite-related minerals to open a new discussion about the taxonomy and nomenclature of the ardennite group.

\section{Occurrence}

The materials studied in this paper have been collected in an area of the central Pelagonian Massif, near the village of Nežilovo. The samples were taken from the riverbeds of the Babuna and Bela rivers, at the base of the Solunska Glava peak, belonging to the Jakupica range (Fig. 1). The samples were broken off the blocks of high metamorphic rocks and transported a short distance from their initial occurrence.

The central part of the Pelagonian Massif is built of highgrade metamorphic and magmatic rocks. The Precambrian high-grade metamorphic series can be divided into the lower and upper parts. The lowest segment of the lower part of the series consists of gneiss on top of which there is a series of mica schists with green mica (Stojanov, 1960). The upper part of the metamorphic series can be divided into the mixed series ("Mešana serija") and the marble series. The mixed series is found on top of the micaceous schists and is composed of gneiss, marble (cipoline), calcite-mica schists, mica schists and chlorite schists, which have their isotopic age estimated as Caledonic (Stojanov, 1960). Above the mixed series, the marble series follows, which is present all the way to the peak of Solunska Glava ( $2540 \mathrm{~m}$ above sea level) (Stojanov, 1960).

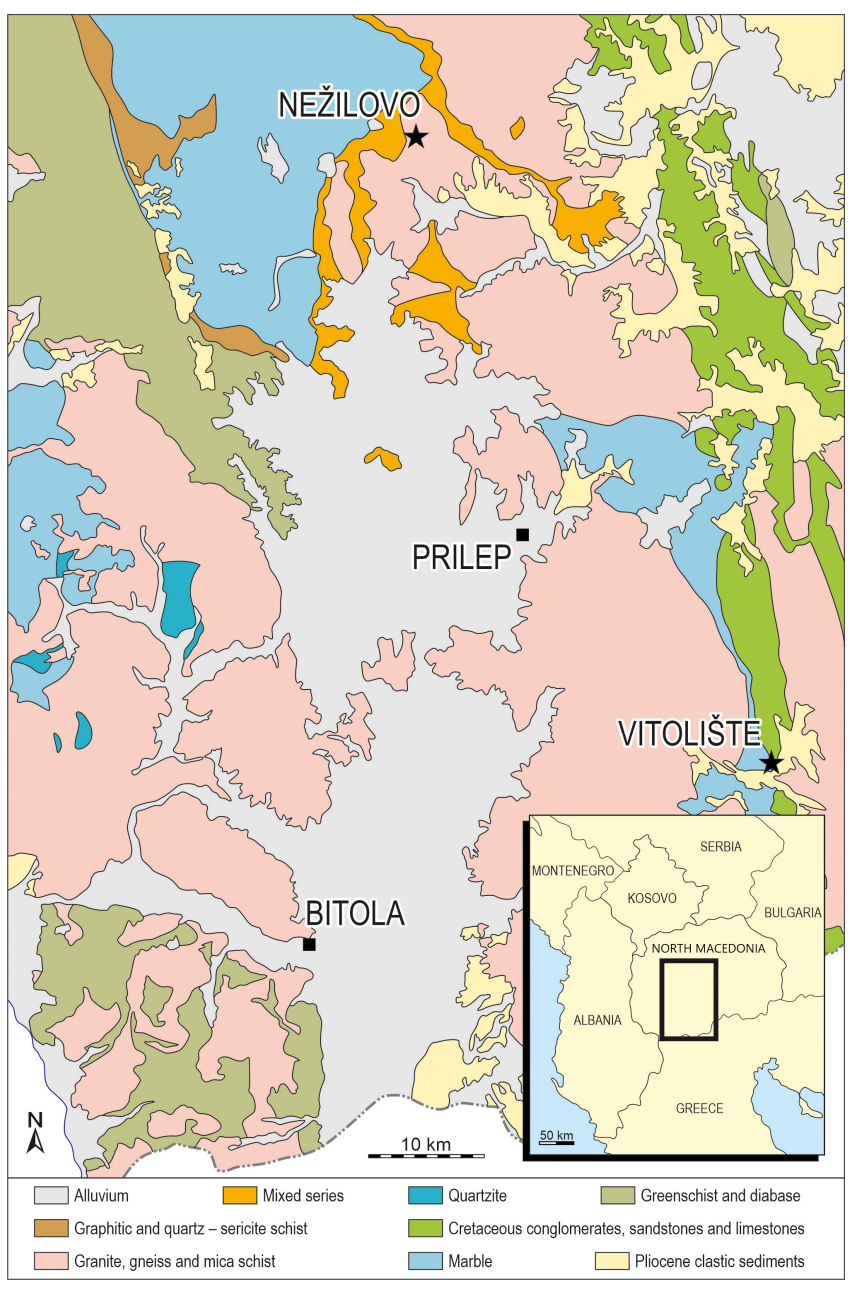

Figure 1. Geological map of the Republic of North Macedonia. The samples were found at $41.66118^{\circ} \mathrm{N}, 21.45426^{\circ} \mathrm{E}$, and the locality has been marked by a black star named Nežilovo. The locality of ardennites found by Altherr et al. (2017) in Vitolište has also been marked. The map was created by the authors.

Ardennite occurs in the upper reaches of the Babuna in two different associations. It is found in a silicate rock (mica schist) and in the pink marble lenses within the mixed series. The mica schists are distinctly red in color from the red mica rich in manganese. In addition to mica, the main mineral is quartz, and the rock typically shows lepidoblastic texture. Ardennite appears between the sheets of mica as brownish-yellow imperfect elongate crystals up to $1 \mathrm{~cm}$ long. Smaller ardennite crystals are shown in the matrix in Fig. 2. The crystals are flattened parallel to the schistosity and show good cleavage almost perpendicular to it and rarely developed terminal faces. Piemontite and red garnet occur in this rock as accessories and are not bigger than $1 \mathrm{~mm}$.

The manganoan dolomite marbles are stained dark red to pink, and it is noticeable that ardennite is unevenly distributed in them. The rock has a granular structure with some randomly oriented grains of mica. In addition to carbonate 


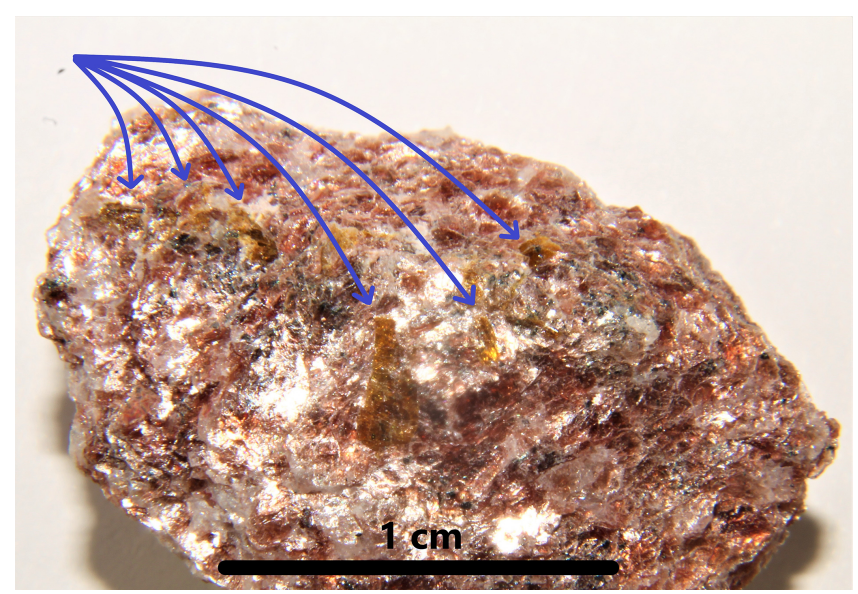

Figure 2. Ardennite in a red mica schist matrix from Nežilovo, North Macedonia.

and ardennite, a number of accessory minerals also occur in the rock: nežilovite (which can occur in significant quantities), colorless to white $\mathrm{Zn}$-rich amphibole, chlorite, piemontite, hematite and dioctahedral mica (colorless, pink, red and honey-brown). Zn-rich amphiboles, including the white amphibole from a similar association, is described as the most Zn-rich amphibole described so far (Chukanov et al., 2020a). Ardennite is closely related to red and honey-brown mica with which it sometimes forms oriented growth, and it can be very difficult to spot and separate them. When separated, this ardennite does not differ from ardennite from mica schists in its physical characteristics, except in the habit, which is more flat to leafy for ardennite from the marbles.

\section{Methods}

A polarizing microscope equipped with a spindle stage was used to determine the optical properties. The directions of optical axes $X, Y$ and $Z$ were measured by the spindle-stage method (Bloss, 1981) on crystals from which the orientation was previously determined by the Buerger precession technique. The optical axial angle was determined on a crystal oriented with the direction of optical axis $Y$ parallel to the spindle axis. Refractive indices were measured with immersion liquids for which the refractive indices were previously determined using the refractometer. The birefringence was obtained from retardation measurements with a Berek compensator, and the thickness was measured with an eyepiece with a moving hairline. Pleochroism was observed on flattened crystal grains about 50 to $100 \mu \mathrm{m}$ thick.

The chemical composition of ardennite was analyzed using an ARL-SEMQ electron microprobe (Museum of Natural History (Naturhistorisches Museum), Vienna) with an operating voltage of $15 \mathrm{kV}$ and a $15 \mathrm{nA}$ current. The electron beam diameter was $10 \mu \mathrm{m}$. The correction was performed based on the method of Bence and Albee (1968).
The WDS-mode electron microprobe analyses of mica were carried out at the Royal Ontario Museum, Canada, using a JEOL 733 Superprobe at an operating voltage of $15 \mathrm{kV}$, an electron beam current of $0.02 \mathrm{nA}$ and a beam diameter of $20 \mu \mathrm{m}$. The Tracor Northern automatization which uses a ZAF correction routine was used for the data processing. Phlogopite was used as a standard for $\mathrm{Si}, \mathrm{K}$ and $\mathrm{Al}$; chlorite was used for $\mathrm{Fe}$ and $\mathrm{Mg}$; tephroite was used for $\mathrm{Mn}$; rutile was used for $\mathrm{Ti}$; albite was used for $\mathrm{Na}$; gehlenite was used for $\mathrm{Ca}$; zincite was used for $\mathrm{Zn}$; cuprite was used for $\mathrm{Cu}$, and sanbornite was used for Ba.

The powder X-ray diffraction (PXRD) patterns were obtained on a Philips vertical X-ray goniometer, using $\mathrm{Cu} K \alpha$ radiation, with a graphite monochromator and $\mathrm{NaCl}$ as an internal standard. The unit cell dimensions were calculated with the aid of the program POWDER (Lindquist and Wengelin, 1967).

X-ray diffraction data of a single crystal were collected on a CAD4 single-crystal diffractometer with graphite monochromatized Mo $K \alpha$ radiation up to $\theta=25^{\circ}$ in $\Omega$ scan mode (Laboratorium für chemische und mineralogische Kristallographie, Bern, Switzerland).

\section{Results}

\subsection{Optical measurements}

Ardennite from Nežilovo shows weak pleochroism in thin sections (brownish-yellow parallel to the elongation and pale yellow perpendicular to the elongation). This feature indicates that minor fractions of manganese and vanadium in the studied sample may occur as $\mathrm{Mn}^{3+}$ and $\mathrm{V}^{3+}$ (Coombs et al., 1993). The grains are usually cracked with noticeable cleavage probably on (010).

The refractive indices are $\alpha=1.537(2), \beta=1.579(1) \gamma=$ 1.741(1), where $\gamma$ corresponds to the $c$ direction. The optical axial angle is $2 V_{x}=49(1)^{\circ}$. Directly measured birefringence is $N_{z}-N_{y}=0.0181(2)$. The dispersion of optical axes is strong: $r<v$.

\subsection{Chemical composition}

Representative data on the chemical composition of ardennite-(As) and related minerals are given in Table 1, and representative chemical data for the dioctahedral mica associated with ardennite-(As) from Nežilovo are presented in Table 2. Contents of other elements with atomic numbers $>8$ are below the detection limits.

The proposed empirical formula of ardennite slightly deviates from the one calculated according to the procedure proposed by Nagashima and Armbruster (2010) and is 


$$
\begin{aligned}
& {\left[\mathrm{Mn}_{3.27}^{2+} \mathrm{Ca}_{0.73}\right]_{\Sigma 4.00}\left[\mathrm{Al}_{4.18} \mathrm{Mg}_{1.24} \mathrm{Fe}_{0.29} \mathrm{Mn}_{0.19}^{3+} \mathrm{Zn}_{0.10}\right]_{\Sigma 6.00}} \\
& \left(\mathrm{Si}_{4.73} \mathrm{Al}_{0.27}\right)_{\Sigma 5.000}\left(\mathrm{As}_{0.96} \mathrm{Si}_{0.03} \mathrm{~V}_{0.01}\right)_{\Sigma 1.00} \mathrm{O}_{22}\left[\mathrm{OH}_{5.36}\right. \\
& \left.\left(\mathrm{H}_{2} \mathrm{O}\right)_{0.64}\right]_{\Sigma 6.00}
\end{aligned}
$$

The average data give an empirical formula of the red mica associated with ardennite-(As) calculated on the basis of 7 cations per formula unit:

$$
\begin{aligned}
& \left(\mathrm{K}_{0.95} \mathrm{Na}_{0.04} \mathrm{Ba}_{0.02}\right)_{\Sigma 1.01}\left(\mathrm{Al}_{1.44} \mathrm{Fe}_{0.30}^{3+} \mathrm{Mg}_{0.20} \mathrm{Mn}_{0.03}\right. \\
& \left.\mathrm{Ti}_{0.02} \mathrm{Zn}_{0.01}\right)_{\Sigma 2.00}\left(\mathrm{Si}_{3.21} \mathrm{Al}_{0.79} \mathrm{O}_{10}\right)\left(\mathrm{OH}_{1.97} \mathrm{O}_{0.03}\right)_{\Sigma 2.00 .}
\end{aligned}
$$

\section{$5.3 \quad X$-ray diffraction}

Ardennite was extracted from both types of rock to perform powder X-ray diffraction. However, due to the intimate intergrowth of ardennite with the mica in the marbles, the PXRD pattern contains reflections of admixed mica, which partly overlaps with the ardennite reflections. Therefore, only the data of the silicate rock sample were used to calculate the unit cell.

The unit cell parameters calculated from the single-crystal data were refined in space group Pnmm; however the complete crystal structure determination is a subject of further study. The calculated unit cell dimensions from this study are compared with a selection of other published data for ardennite-group minerals in Table 3.

\section{Discussion}

According to reviewed published papers about ardennite and related minerals, it is obvious that there are several well-defined end-members. The ardennite group is not approved officially; however it exists de facto. Currently, four mineral species isotypical with ardennite(As) are found in nature. However, a large number of possible substitutions at the $A, M$ and $T 4$ sites make it possible to suppose the existence of other endmembers. The general formula of these minerals could be $A_{4} M 1_{2} M 2_{2} M 3_{2}\left(T 1 \mathrm{O}_{4}\right)\left(T 2 \mathrm{O}_{4}\right)\left(T 3_{3} \mathrm{O}_{10}\right)\left(T 4 \mathrm{O}_{4}\right)(X)_{6}$, where $A$ is $\mathrm{Mn}^{2+}, \mathrm{Ca}, \mathrm{Cu}^{2+}$ and $\mathrm{Mg} ; M 1,2$ is $\mathrm{Al}, \mathrm{Mn}^{3+}$, $\mathrm{Cu}^{2+}, \mathrm{Ni}^{2+}, \mathrm{Zn}, \mathrm{Fe}^{2+}, \mathrm{Fe}^{3+}, \mathrm{Cr}^{3+}, \mathrm{V}^{3+}$ and $\mathrm{Ti} ; M 3$ is $\mathrm{Al}$, $\mathrm{Mn}^{3+}$ and $\mathrm{Mg} ; T 1$ is $\mathrm{Si}, \mathrm{Al}$ and $\mathrm{B} ; T 2$ and $T 3$ are $\mathrm{Si} ; T 4$ is As, $\mathrm{V}, \mathrm{Si}$ and $\mathrm{P}$; and $\mathrm{X}$ is $\mathrm{OH}, \mathrm{F}$ and $\mathrm{O}$.

Frost et al. (2014) used Raman and IR spectroscopy to prove the presence of $\mathrm{H}_{2} \mathrm{O}$ in the structure of ardennite-(As), thus questioning if $\mathrm{H}_{2} \mathrm{O}$ should also be added at the $X$ site. Similar ideas were suggested by Chukanov (2014).

In most cases, the dominant components at the $A$ and $T 4$ sites can be determined with a high reliability based on chemical analyses, which is consistent with the results by Xray structural analysis (Nagashima and Armbruster, 2010).
Therefore, it would be reasonable to assume the occupancies of the $A$ and $T 4$ sites as the basis of the ardennite-group nomenclature, whereas it is difficult to determine the site occupancy at the $M$ site with only one analytical method. However, the $M$ sites, as well as possibly the $X$ site, may be considered species-defining provided that their occupancies have been determined reliably, as in the cases of alpeite and kannanite. Nagashima and Armbruster (2010) performed one approach by complementary application of the results by EMPA and X-ray structural analyses, although multimethodical studies may not always be possible. Some other mineral species that are closely related to the ardennitegroup minerals but are not completely isostructural with them should not be considered part of the group. For example, lavoisierite is structurally related to ardennite, but it has a doubled $c$ parameter when compared to ardennite. Another example is orientite, which is a crystallochemically related hydrous mineral.

Based on the chemical variations of ardennite-group minerals from different localities, one could expect a lot of potential end-members. However, the number of possible ardennite-group minerals is restricted by both geochemical and crystal-chemical reasons. From the data in Fig. 3, one can conclude that there are $\mathrm{V}-\mathrm{Si}$ and restricted $\mathrm{As}-\mathrm{Si}$ solid solutions, whereas the As-V solid solution has not yet been observed. It is interesting to see that the most common elements entering the $T 4$ site are $\mathrm{As}^{5+}, \mathrm{V}^{5+}, \mathrm{Si}^{4+}$ and $\mathrm{P}^{5+}$. The ionic radii of these ions in a tetrahedral coordination are $0.475,0.495,0.400$ and $0.350 \AA$, respectively (Shannon and Prewitt, 1969). With the ionic radii of $\mathrm{As}^{5+}$ and $\mathrm{V}^{5+}$ being the closest to each other, one can suppose a geochemical cause for the absence of the As-V solid solution. The As-Si solid solution might also be restricted as the data for most intermediate members refer to the material from Vitolište which may have a lavoisierite-type structure with the doubled $c$ parameter (Altherr et al., 2017). Nevertheless, restricted As-Si and V-Si substitutions have been observed with the highest Si occupancy of 0.315 atoms at the $T 4$ site in an ardennite-(V)-type material (Barresi et al., 2007). This also raises the question of finding possible "ardennite-(Si)" with over $0.5 \mathrm{Si}$ atoms at the $T 4$ site. The $\mathrm{Si}^{4+}$ ion is $16 \%$ smaller than $\mathrm{As}^{5+}$ and $20 \%$ smaller than the $\mathrm{V}^{5+}$ ion, which are both values above the conventional $15 \%$ ionic radii difference tolerance for the substitutions. This might be an obstacle for the formation of a continuous and complete solid solution series due to more significant difference between the atomic radii of $\mathrm{Si}$ compared to $\mathrm{As}$ and $\mathrm{V}$. The presence of $\mathrm{Si}$ at the $T 4$ site in ardennite-group minerals was first discussed by Pasero and Reinecke (1991), who gave two possible models of the structure of the Si end-member, both with a doubled $c$ parameter caused by the deformation of the $T 4$ site polyhedral. Orlandi et al. (2013) determined the ardennite and sursassite groups and described lavoisierite structure as a polysome with alternating ardennite-like and sursassitelike slabs. Altherr et al. (2017) determined the presence of a 
Table 1. Representative electron microprobe analysis data of ardennite-group minerals from this study and previous papers.

\begin{tabular}{|c|c|c|c|c|c|c|c|}
\hline & $\begin{array}{r}\text { Nežilovo } \\
\text { (this work)* }^{*}\end{array}$ & $\begin{array}{r}\text { Salm Chateau } \\
\text { (Nagashima and } \\
\text { Armbruster, 2010) }\end{array}$ & $\begin{array}{r}\text { Vernetto, Italy } \\
\text { (Nagashima and } \\
\text { Armbruster, 2010) }\end{array}$ & $\begin{array}{r}\text { OU62028 } \\
\text { (Coombs et } \\
\text { al., 1993) }\end{array}$ & $\begin{array}{r}\text { Ardennite-(V) } \\
\text { (Barresi et } \\
\text { al., 2007) }\end{array}$ & $\begin{array}{r}\text { Kannanite } \\
\text { (Nishio-Hamane et } \\
\text { al., 2018) }\end{array}$ & $\begin{array}{r}\text { Alpeite } \\
\text { (Kampf et } \\
\text { al., 2017) }\end{array}$ \\
\hline Component & $\mathrm{Wt} \%$ & & & & & & \\
\hline $\mathrm{SiO}_{2}$ & 27.40 & 28.39 & 30.51 & 28.93 & 31.21 & 29.37 & 29.92 \\
\hline $\mathrm{TiO}_{2}$ & - & 0.00 & 0.09 & 0.06 & 0.21 & - & - \\
\hline $\mathrm{Al}_{2} \mathrm{O}_{3}$ & 21.70 & 24.45 & 21.78 & 23.41 & 22.60 & 14.40 & 11.52 \\
\hline $\mathrm{Cr}_{2} \mathrm{O}_{3}$ & - & 0.05 & 0.04 & - & 0.34 & - & - \\
\hline $\mathrm{FeO}$ & 1.97 & - & - & - & - & - & - \\
\hline $\mathrm{Fe}_{2} \mathrm{O}_{3}$ & - & - & 0.90 & 1.26 & 1.64 & 5.18 & - \\
\hline $\mathrm{MnO}$ & 23.50 & 23.88 & 23.27 & 23.64 & 22.33 & 3.89 & 1.08 \\
\hline $\mathrm{Mn}_{2} \mathrm{O}_{3}$ & - & - & - & 0.75 & 1.06 & 9.74 & 19.70 \\
\hline $\mathrm{MgO}$ & 4.80 & 3.44 & 4.20 & 3.53 & 4.44 & 2.70 & 2.49 \\
\hline $\mathrm{CaO}$ & 3.90 & 1.39 & 4.03 & 2.74 & 4.24 & 19.02 & 20.45 \\
\hline $\mathrm{As}_{2} \mathrm{O}_{5}$ & 10.60 & 10.27 & 7.46 & 9.04 & 0.37 & 1.52 & 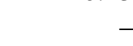 \\
\hline $\mathrm{V}_{2} \mathrm{O}_{5}$ & 0.10 & 0.51 & 0.33 & 0.19 & 4.60 & 6.04 & 7.36 \\
\hline $\mathrm{P}_{2} \mathrm{O}_{5}$ & - & - & 0.23 & 0.03 & 0.38 & - & - \\
\hline $\mathrm{ZnO}$ & 0.80 & - & - & 0.05 & - & - & - \\
\hline $\mathrm{NiO}$ & - & 0.00 & 0.04 & 0.06 & - & 0.40 & - \\
\hline $\mathrm{CuO}$ & - & 0.54 & 0.14 & 0.25 & - & 0.34 & - \\
\hline $\mathrm{Na}_{2} \mathrm{O}$ & - & 0.01 & 0.01 & - & 0.02 & - & - \\
\hline $\mathrm{K}_{2} \mathrm{O}$ & - & 0.01 & 0.01 & - & - & - & - \\
\hline $\mathrm{BaO}$ & - & - & - & 0.02 & - & - & - \\
\hline $\mathrm{B}_{2} \mathrm{O}_{3}$ & - & - & - & 0.23 & - & - & - \\
\hline $\mathrm{CoO}$ & - & - & - & - & - & - & 1.43 \\
\hline $\mathrm{F}$ & - & - & - & - & 0.17 & - & 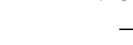 \\
\hline$-\mathrm{O}=\mathrm{F}$ & - & - & - & - & -0.07 & - & - \\
\hline $\mathrm{H}_{2} \mathrm{O}$ & 5.23 & 4.96 & 5.80 & 5.3 & 5.70 & 5.22 & 5.13 \\
\hline Total: & $100 \%$ & $97.90 \%$ & $98.84 \%$ & $99.46 \%$ & $99.24 \%$ & $97.83 \%$ & $99.08 \%$ \\
\hline \multicolumn{8}{|c|}{ Formula coefficients } \\
\hline $\mathrm{Si}$ & 4.76 & 5.04 & 5.32 & 5.039 & 5.315 & 4.16 & 4.25 \\
\hline $\mathrm{Ti}$ & - & - & 0.01 & 0.08 & 0.027 & - & - \\
\hline $\mathrm{Al}$ & 4.45 & 5.11 & 4.48 & 4.860 & 4.536 & 3.00 & 4.45 \\
\hline $\mathrm{Cr}$ & - & 0.01 & 0.01 & - & 0.046 & - & - \\
\hline $\mathrm{Fe}$ & 0.29 & - & 0.12 & 0.165 & 0.210 & 0.69 & - \\
\hline $\mathrm{Mn}$ & 3.46 & 3.59 & 3.44 & 3.587 & 3.358 & 1.90 & 2.79 \\
\hline $\mathrm{Mg}$ & 1.24 & 0.91 & 1.09 & 0.916 & 1.127 & 0.71 & 0.65 \\
\hline $\mathrm{Ca}$ & 0.73 & 0.26 & 0.75 & 0.509 & 0.774 & 3.60 & 3.84 \\
\hline As & 0.96 & 0.95 & 0.68 & 0.823 & 0.033 & 0.14 & - \\
\hline $\mathrm{V}$ & 0.01 & 0.06 & 0.04 & 0.022 & 0.518 & 0.70 & 0.85 \\
\hline $\mathrm{P}$ & - & - & 0.03 & 0.005 & 0.055 & - & - \\
\hline $\mathrm{Zn}$ & 0.10 & - & - & 0.006 & - & - & - \\
\hline $\mathrm{Ni}$ & - & - & 0.01 & 0.009 & - & 0.06 & - \\
\hline $\mathrm{Cu}$ & - & 0.07 & 0.02 & 0.033 & - & 0.05 & - \\
\hline $\mathrm{Na}$ & - & - & - & - & 0.006 & - & - \\
\hline $\mathrm{Ba}$ & - & - & - & 0.002 & - & - & - \\
\hline B & - & - & - & 0.069 & - & - & - \\
\hline $\mathrm{Co}$ & - & - & - & - & - & - & 0.20 \\
\hline $\mathrm{F}$ & - & - & - & - & 0.092 & - & - \\
\hline $\mathrm{H}$ & 5.80 & 5.872 & 6.75 & 6.17 & 6.47 & 6.16 & 6 \\
\hline Cations & $\Sigma=55.16$ & & & & & & \\
\hline
\end{tabular}

* A single analysis. 
Table 2. Representative microprobe analysis of red mica associated with ardennite-(As) in mica schist from Nežilovo.

\begin{tabular}{|c|c|c|c|}
\hline \multirow[b]{2}{*}{$\mathrm{Wt} \%$} & \multicolumn{3}{|c|}{ Spot analysis number } \\
\hline & 1 & 2 & 3 \\
\hline $\mathrm{SiO}_{2}$ & 46.75 & 46.94 & 46.82 \\
\hline $\mathrm{TiO}_{2}$ & 0.33 & 0.40 & 0.42 \\
\hline $\mathrm{Al}_{2} \mathrm{O}_{3}$ & 27.36 & 27.65 & 27.79 \\
\hline $\mathrm{Fe}_{2} \mathrm{O}_{3}$ & 5.85 & 5.80 & 5.72 \\
\hline $\mathrm{MnO}$ & 0.57 & 0.54 & 0.50 \\
\hline $\mathrm{MgO}$ & 1.99 & 2.05 & 2.00 \\
\hline $\mathrm{Na}_{2} \mathrm{O}$ & 0.36 & 0.30 & 0.25 \\
\hline $\mathrm{K}_{2} \mathrm{O}$ & 10.79 & 10.78 & 10.97 \\
\hline $\mathrm{BaO}$ & 0.73 & 0.72 & 0.66 \\
\hline $\mathrm{ZnO}$ & 0.12 & 0.16 & 0.13 \\
\hline $\mathrm{H}_{2} \mathrm{O}$ & 4.30 & 4.33 & 4.33 \\
\hline Total & 99.15 & 99.67 & 99.59 \\
\hline $\mathrm{Si}$ & 3.21 & 3.20 & 3.21 \\
\hline $\mathrm{Ti}$ & 0.02 & 0.02 & 0.02 \\
\hline $\mathrm{Al}$ & 2.21 & 2.23 & 2.24 \\
\hline $\mathrm{Fe}$ & 0.30 & 0.30 & 0.30 \\
\hline $\mathrm{Mn}$ & 0.03 & 0.03 & 0.03 \\
\hline $\mathrm{Mg}$ & 0.20 & 0.21 & 0.20 \\
\hline $\mathrm{Na}$ & 0.05 & 0.04 & 0.03 \\
\hline K & 0.95 & 0.94 & 0.95 \\
\hline $\mathrm{Ba}$ & 0.02 & 0.02 & 0.02 \\
\hline $\mathrm{Zn}$ & 0.01 & 0.01 & 0.01 \\
\hline $\mathrm{H}$ & 1.97 & 1.97 & 1.97 \\
\hline Cations except $\mathrm{H}$ & 7.00 & 7.00 & 7.00 \\
\hline
\end{tabular}

complete $\mathrm{Si}-\mathrm{V}$ solid solution series but did not confirm the same type of crystal structure by X-ray diffraction. The list of dominant species-defining elements at each site for every mineral of the ardennite group can be found in Table 4, and the end-member formulae can be found in Table 5. including some hypothetical end-members as well.

The formula of ardennite-(As) given in this paper slightly deviates from the formula that would be obtained by following the latest proposition of calculating the formulae of ardennite-group minerals (Nagashima and Armbruster, 2010). The earlier papers used the procedure proposed in Reinecke and Hatzipanagotou (1987), which normalized the number of $\mathrm{O}$ atoms to 28 . The formula obtained for the Nežilovo ardennite-(As) using this approach would be

$\left[\mathrm{Mn}_{3.27}^{2+} \mathrm{Ca}_{0.73}\right]_{\Sigma 4.00}\left[\mathrm{Al}_{4.18} \mathrm{Mg}_{1.24} \mathrm{Fe}_{0.29} \mathrm{Mn}_{0.19}^{3+}\right.$

$\left.\mathrm{Zn}_{0.10}\right]_{\Sigma 6.00}\left(\mathrm{Si}_{4.73} \mathrm{Al}_{0.27}\right)_{5.000}\left(\mathrm{As}_{0.96} \mathrm{Si}_{0.03} \mathrm{~V}_{0.01}\right)_{\Sigma 1.00}$

$\mathrm{O}_{21.36}(\mathrm{OH})_{6.64}$.

A new approach was first suggested in Coombs et al. (1993) and was put into practice by Nagashima and Armbruster (2010) because they showed that the OH content of ardennite should not exceed 6 atoms per formula unit (apfu), which was the case in earlier papers. This procedure first normalizes the number of cations, except $\mathrm{H}$, to 16 . Then the $T$ positions are solved by collecting $\mathrm{Si}, \mathrm{As}, \mathrm{V}$ and $\mathrm{P}$ cations. If there is more than 6 apfu in the $T$ position, the excess $\mathrm{V}$ is assigned to octahedrally coordinated sites as $\mathrm{V}^{3+}$, and if there are insufficient cations, the lack is compensated for with $\mathrm{Al}$. Then, the amount of $\mathrm{OH}$ is determined by the requirement of electroneutrality. At the end, if $(\mathrm{Ca}+\mathrm{Mn})$ content exceeds $4 \mathrm{apfu}$, then the excess $\mathrm{Mn}$ is assigned to octahedrally coordinated sites as $\mathrm{Mn}^{3+}$. The formula of the studied ardennite-(As) following this approach is

$\left[\mathrm{Mn}_{3.27}^{2+} \mathrm{Ca}_{0.73}\right]_{\Sigma 4.00}\left[\mathrm{Al}_{4.18} \mathrm{Mg}_{1.24} \mathrm{Fe}_{0.29} \mathrm{Mn}_{0.19}^{3+} \mathrm{Zn}_{0.10}\right]_{\Sigma 6.00}$ $\left(\mathrm{Si}_{4.73} \mathrm{Al}_{0.27}\right)_{5.000}\left(\mathrm{As}_{0.96} \mathrm{Si}_{0.03} \mathrm{~V}_{0.01}\right)_{\Sigma 1.00} \mathrm{O}_{21.78}(\mathrm{OH})_{5.80}$.

However, this approach implies vacancies in the anionic sites where there are no implications for their presence. Furthermore, in the IR spectrum of ardennite-(As) from its type locality, a weak band of $\mathrm{H}_{2} \mathrm{O}$ at $1620 \mathrm{~cm}^{-1}$ is present (Chukanov, 2014), which does not correspond to weakly bonded, adsorbed water in the $\mathrm{KBr}$ pellet that absorbs at $1640 \mathrm{~cm}^{-1}$. If we suppose minor substitution of $\mathrm{OH}$ by $\mathrm{H}_{2} \mathrm{O}$ in ardennite, the formula could be written as follows:

$$
\begin{aligned}
& {\left[\mathrm{Mn}_{3.27}^{2+} \mathrm{Ca}_{0.73}\right]_{\Sigma 4.00}\left[\mathrm{Al}_{4.18} \mathrm{Mg}_{1.24} \mathrm{Fe}_{0.29} \mathrm{Mn}_{0.19}^{3+} \mathrm{Zn}_{0.10}\right]_{\Sigma 6.00}} \\
& \left(\mathrm{Si}_{4.73} \mathrm{Al}_{0.27}\right)_{5.000}\left(\mathrm{As}_{0.96} \mathrm{Si}_{0.03} \mathrm{~V}_{0.01}\right)_{\Sigma 1.00} \mathrm{O}_{22}\left[\mathrm{OH}_{5.36}\right. \\
& \left.\left(\mathrm{H}_{2} \mathrm{O}\right)_{0.64}\right]_{\Sigma 6.00}
\end{aligned}
$$

This approach would be a good compromise between achieving electroneutrality and satisfying the occupancy of the anionic sites.

Due to significant differences, primarily in the line intensities between PXRD data of ardennite from Nežilovo and those from the type locality in Belgium (Moore, 1965), single-crystal X-ray diffraction data were also collected. However, the structural factors for the Salm Chateau sample of Donnay and Allmann (1968) and for that of Nežilovo do not differ significantly. It is evident that the unit cell parameters increase with the substitution of $\mathrm{Mn}^{2+}$ with $\mathrm{Ca}^{2+}$ at the $A$ site (Table 4). In particular, alpeite and kannanite have larger unit cell parameters than ardennite-(As) and ardennite(V). The mixed series of the Pelagonian Massif represents the second occurrence of an ardennite-group mineral in North Macedonia, the first one being the Vardar zone near Vitolište, where ardennite-(V) was described by Altherr et al. (2017). These two localities are situated about $50 \mathrm{~km}$ away from each other and belong to two different complexes, the Pelagonian and Vardar zones (Fig. 1). Accordingly, the two mineral members show different chemical composition despite both of them being formed in similar low-grade metamorphic conditions.

The micas from Nežilovo and their polytypism have been extensively explored (Kudrnovski, 1997). The data obtained indicate high $P / T$ ratio conditions of crystallization as well as a high oxygen fugacity and oxidative forming conditions of the rock. These conditions match 
Table 3. Unit cell dimensions of ardennite-(As) and related minerals.

\begin{tabular}{|c|c|c|c|c|c|c|}
\hline Mineral & Locality & $a(\AA)$ & $b(\AA)$ & $c(\AA)$ & $V\left(\AA^{3}\right)$ & Source \\
\hline Ardennite-(As) & $\begin{array}{l}\text { Nežilovo, North } \\
\text { Macedonia }{ }^{b}\end{array}$ & $8.760(1)$ & $5.838(1)$ & $18.582(2)$ & 950.30 & This work \\
\hline Ardennite-(As) & Salm Chateau, Belgium & $8.713(1)$ & $5.811(1)$ & $18.521(1)$ & 937.74 & Donnay and Allmann (1968) \\
\hline Ardennite-(As) & Salm Chateau, Belgium & $8.744(16)$ & $5.794(9)$ & $18.423(26)$ & 933.36 & Moore (1965) \\
\hline Ardennite-(As) & $\begin{array}{l}\text { Salm Chateau, } \\
\text { Belgium }\end{array}$ & $8.7163(2)$ & $5.8131(1)$ & $18.5199(3)$ & $938.38(3)$ & Nagashima and Armbruster (2010) \\
\hline Ardennite-(As) & Kajlidongri, India & $8.707(5)$ & $5.807(4)$ & $18.570(1)$ & 938.928 & Nayak (1967) \\
\hline Ardennite-(As) & $\begin{array}{l}\text { Haast Schist Group, } \\
\text { West Otago, New } \\
\text { Zealand }\end{array}$ & $8.721(1)$ & $5.816(1)$ & $18.545(3)$ & $940.7(2)$ & Coombs et al. (1993) \\
\hline Ardennite-(V) (type material) & Sparone, Italy & $8.760(3)$ & $5.838(2)$ & $18.56(2)$ & $949.34(2)$ & Barresi et al. (2007) \\
\hline Alpeite (type material) & Monte Alpe Mine, Italy & $8.9421(11)$ & $6.0534(6)$ & $18.9781(18)$ & $1027.29(19)$ & Kampf et al. (2017) \\
\hline
\end{tabular}

${ }^{a}$ From powder data. ${ }^{b}$ From single-crystal data.

Table 4. Dominant components at the structural sites of the ardennite-group minerals.

\begin{tabular}{llllllllll}
\hline & $A$ & $M 1$ & $M 2$ & $M 3$ & $T 1$ & $T 2$ & $T 3$ & $T 4$ & $X$ \\
\hline Ardennite-(As) & $\mathrm{Mn}^{2+}$ & $\mathrm{Al}$ & $\mathrm{Al}$ & $\mathrm{Al}, \mathrm{Mg}$ & $\mathrm{Si}$ & $\mathrm{Si}$ & $\mathrm{Si}$ & $\mathrm{As}$ & $\mathrm{OH}$ \\
Ardennite-(V) & $\mathrm{Mn}^{2+}$ & $\mathrm{Al}$ & $\mathrm{Al}$ & $\mathrm{Al}, \mathrm{Mg}$ & $\mathrm{Si}$ & $\mathrm{Si}$ & $\mathrm{Si}$ & $\mathrm{V}$ & $\mathrm{OH}$ \\
Alpeite & $\mathrm{Ca}$ & $\mathrm{Mn}^{3+}$ & $\mathrm{Al}$ & $\mathrm{Mn}^{3+}, \mathrm{Mg}$ & $\mathrm{Si}$ & $\mathrm{Si}$ & $\mathrm{Si}$ & $\mathrm{V}$ & $\mathrm{OH}$ \\
Kannanite & $\mathrm{Ca}$ & $\mathrm{Al}$ & $\mathrm{Al}$ & $\mathrm{Al}, \mathrm{Mg}$ & $\mathrm{Si}$ & $\mathrm{Si}$ & $\mathrm{Si}$ & $\mathrm{V}$ & $\mathrm{OH}$ \\
\hline
\end{tabular}

the forming conditions of ardennite-type minerals suggested by Semet and Moreau (1965). Phengites, ideally $\mathrm{KAl}_{1.5}(\mathrm{Mg}, \mathrm{Fe})_{0.5}\left(\mathrm{Al}_{0.5} \mathrm{Si}_{3.5} \mathrm{O}_{10}\right)(\mathrm{OH})_{2}$, which are the dominant micas in these rocks, crystallized as the $2 M_{1}$ polytype. However, the largest part of phengite- $2 M_{1}$ in Nežilovo formed as a result of recrystallization of phengite- $3 T(\mathrm{Ku}-$ drnovski, 1997). The presence of the $3 T$ polytype suggests a higher $P / T$ ratio of metamorphism. This recrystallization could occur with the decrease in pressure or increase in temperature (see e.g., Yoder and Eugster, 1955; Sassi et al., 1994). The high $P / T$ ratio in the evolution of the mixed series at Nežilovo is further confirmed by the presence of $\mathrm{Ti}$ in the crystal structure of phengites (Table 2) that is assumed to be an effect of the saturated phase (rutile, ilmenite) during the crystallization process (Bailey, 1984). It has been determined that the celadonite component decreases with the increase in temperature of crystallization (Bailey, 1984), also implying lower temperatures in Nežilovo.

In order to approximate the $P-T$ conditions, an empirical phengite geobarometer was used (Kamzolkin et al., 2016). These authors proposed two different empirical formulae for the phengite geobarometer for temperatures below $750^{\circ} \mathrm{C}$ : one for phengites with less than $3.25 \mathrm{Si}$ apfu and the second one with more than $3.25 \mathrm{Si}$ apfu. The studied ardennite sample has slightly below $3.25 \mathrm{Si}$ apfu; however the second equa- tion was chosen since the $\mathrm{Si} / \mathrm{Al}$ ratio of 1.43 is significantly greater than 1.3.

Majer and Mason (1983) worked on the same part of the Pelagonian Massif and determined the regional metamorphism conditions to be in the range of $450-500{ }^{\circ} \mathrm{C}$. For this temperature range, the empirical phengite geobarometer gives the pressure between 13 and $15 \mathrm{kbar}$, which is in accordance with the proposed pressure range of Majer and Mason (1983) as well. Such associations suggest that the mixed series is a result of multiple metamorphic processes that occurred in this complex including a high-pressure event or events. Similar results are derived for Vitolište (Altherr et al., 2017), where ardennite-(V) has been found in Upper Cretaceous meta-conglomerates of the Vardar zone. The authors described a paragenesis which suggests high-pressure metamorphic conditions of about $6.5-8.0 \mathrm{kbar}$ and $340-370^{\circ} \mathrm{C}$. In Vitolište, ardennite-(V) shows an essential substitution of $\mathrm{V}$ by Si (Altherr et al., 2017). The occurrences of ardennitegroup minerals on the edges of two zones (the Vardar zone and the Pelagonian Massif) provide evidence for the similar conditions of metamorphism.

Kudrnovski (1997) found that micas of the Pelagonian zone had formed in various metamorphic conditions. This supports the hypothesis of there being more than one metamorphic stage. These multiple metamorphic events make the determination of the rock age as well as the times of differ- 
Table 5. End-member formulae of the ardennite-group minerals.

\begin{tabular}{ll}
\hline Mineral & Formula \\
\hline$A=\mathrm{Mn}^{2+}$ & \\
\hline Ardennite-(As) & $\mathrm{Mn}_{4}^{2+} \mathrm{Al}_{4}(\mathrm{AlMg})\left(\mathrm{AsO}_{4}\right)\left(\mathrm{SiO}_{4}\right)_{2}\left(\mathrm{Si}_{3} \mathrm{O}_{10}\right)(\mathrm{OH})_{6}$ \\
Ardennite-(V) & $\mathrm{Mn}_{4}^{2+} \mathrm{Al}_{4}(\mathrm{AlMg})\left(\mathrm{VO}_{4}\right)\left(\mathrm{SiO}_{4}\right)_{2}\left(\mathrm{Si}_{3} \mathrm{O}_{10}\right)(\mathrm{OH})_{6}$ \\
"Ardennite-( $\mathrm{Si})$ "** & $\mathrm{Mn}_{4}^{2+} \mathrm{Al}_{4}(\mathrm{AlMg})\left(\mathrm{SiO}_{4}\right)\left(\mathrm{SiO}_{4}\right)_{2}\left(\mathrm{Si}_{3} \mathrm{O}_{10}\right)(\mathrm{OH})_{6}(?)$ \\
\hline$A=\mathrm{Ca}$ & \\
\hline Alpeite & $\mathrm{Ca}_{4} \mathrm{Mn}_{2}^{3+} \mathrm{Al}_{2}\left(\mathrm{Mn}^{3+} \mathrm{Mg}_{(2)}\left(\mathrm{VO}_{4}\right)\left(\mathrm{SiO}_{4}\right)_{2}\left(\mathrm{Si}_{3} \mathrm{O}_{10}\right)(\mathrm{OH})_{6}\right.$ \\
Kannanite & $\mathrm{Ca}_{4} \mathrm{Al}_{4}\left(\mathrm{AlMg}_{2}\left(\mathrm{VO}_{4}\right)\left(\mathrm{SiO}_{4}\right)_{2}\left(\mathrm{Si}_{3} \mathrm{O}_{10}\right)(\mathrm{OH})_{6}\right.$ \\
\hline
\end{tabular}

* Not approved by the IMA CNMNC.

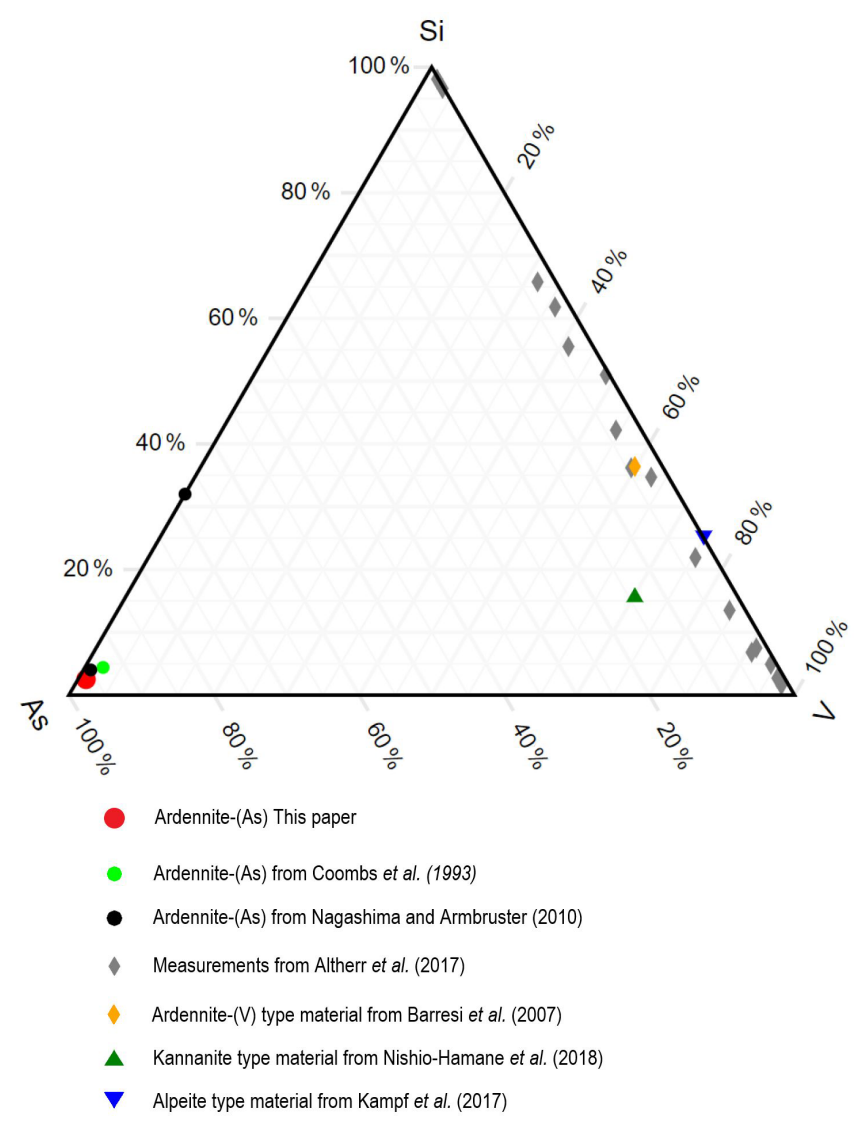

Figure 3. Ternary diagram showing the $T 4$ site occupancy in ardennite and related minerals from this paper and selected literature sources. The data for the samples from Altherr et al. (2017) may partly correspond to lavoisierite. ent metamorphic stages hard; however the sequence can be divided into three major stages.

\subsection{Stage 1 - sedimentation}

The first Precambrian stage is characterized by sedimentation of chemically very diverse sediments. These sediments had a very peculiar chemistry and a unique combination of elements which later on produced the uniqueness of the Nežilovo area. These elements, especially the chalcophile ones, had a significant role in the evolution of the locality and the formation of unusual minerals.

\subsection{Stage 2 - high-grade (and high-pressure) metamorphism}

The sediments accumulated in the Nežilovo area during the first stage experienced a high-grade metamorphic event that is most evident in an area between the Pelagonian Massif and the Vardar zone where proof of a blueschist facies has been found and conditions of temperature between 450 and $500{ }^{\circ} \mathrm{C}$ and pressures around $14 \mathrm{kbar}$ or lower have been suggested (Majer and Mason, 1983). The same authors describe some characteristics of an eclogite facies such as an omphacite association in some samples and interpret garnets as relicts of the previous meta-sediment rocks. These high-grade regional metamorphic rocks are the main setting of the central part of the Pelagonian Massif (Stojanov, 1968), and this event probably occurred before the upper Carboniferous granitic intrusions described by Mountrakis (1984).

\subsection{Stage 3 - retrograde metamorphism}

As the meta-sediments were pushed upwards into an area of lower pressure via geotectonic movements, the temperature was also decreased. The formation of phengite- $2 M_{1}$ could occur at a lowered pressure or at an enhanced temperature compared to those present in Stage 2. Until we have clear evidence for the source of heat at a higher depth, the lowering of pressure is an acceptable conclusion for this stage 
of the deposit evolution. This led to the recrystallization of phengite- $3 T$ into phengite- $2 M_{1}$, which is a stable polytype at low pressures.

Ardennite-(As) formed in the third stage, under the lowgrade metamorphic conditions. The presence of ardennite(As), as well as of other low-grade metamorphic minerals (chlorite, colorless amphibole, cymrite; Jančev, 1978; Bermanec, 1992), suggests that this part of the Pelagonian complex has recently gone through a stage of retrograde metamorphism matching the greenschist facies. The process of metamorphism finished before the rock was exposed to exogenous processes. It is also important to note the occurrence of ardennite-(As) in a carbonate environment which has not yet been reported in other literature. The formation of this deposit is a result of metamorphism of originally chemically complex carbonate sediments.

The occurrence of chalcophile elements $(\mathrm{Zn}, \mathrm{Pb}, \mathrm{Sb}, \mathrm{Cu}$ and As) coupled with the lack of sulfides and sulfosalts is a specific feature of the Nežilovo ore occurrences (Chukanov et al., 2015). The highest concentrations of chalcophile elements are confined to the exocontact zone of a metarhyolite body with marbles as well as cymrite, baryte and mica schists. Postmagmatic fluid is considered an additional source of rare and chalcophile elements (Ermolaeva et al., 2016). The chalcophile metals do not form sulfides and sulfosalts but occur as components of diverse oxygen-bearing minerals (mainly oxides), including very rare and potentially new mineral species. Out of the five newly described minerals in Nežilovo, four are oxides and only piemontite- $(\mathrm{Pb})$ is a silicate.

The absence of sulfides and sulfosalts is due to two factors: a highly oxidative environment (Bermanec, 1992) and a high activity of barium at all stages of the evolution of the mixed series, which resulted in the immobilization of sulfur in accordance with the scheme $\mathrm{S}^{2-}+2 \mathrm{O}_{2} \leftrightarrow \mathrm{SO}_{4}^{2-} ; \mathrm{SO}_{4}^{2-}+$ $\mathrm{Ba}^{2+} \rightarrow \mathrm{BaSO}_{4} \downarrow$ (Chukanov et al., 2020b). During the formation of ardennite-(As), as well as during all other stages of the mixed series formation, the $\mathrm{Ba}: \mathrm{S}$ atomic ratio was greater than 1 (Ermolaeva et al., 2017). The enrichment in $\mathrm{Zn}$ is a specific feature of ardennite-(As) from the Nežilovo area. The sample studied in this work contains $0.103 \mathrm{Zn}$ apfu (Table 1), which is the greatest zinc content among all analyzed ardennite-group minerals.

\section{Conclusions}

Ardennite-group minerals have a general formula $A_{4} M 1_{2} M 2_{2} M 3_{2}\left(T 1 \mathrm{O}_{4}\right)\left(T 2 \mathrm{O}_{4}\right)\left(T 3_{3} \mathrm{O}_{10}\right)\left(T 4 \mathrm{O}_{4}\right)(X)_{6}$.

The presence of three different $M$ sites in the structure of these minerals, as well as four tetrahedral positions, often makes the determination of dominant components at each structural site hard to do. Because of the highest reliability of chemical analyses and consistency with the results by $\mathrm{X}$-ray structural analysis, the occupancies of $A$ and $T 4$ sites are suggested as the basis of the ardennite-group nomenclature. The $M$ sites, and possibly the $X$ site, could also be considered species-defining; however, it should be noted that this could only be possible with a reliable structural determination of each site, as in the cases of alpeite and kannanite.

The metamorphic conditions of formation and the chemical variations of ardennite-group minerals could produce a number of potential end-members, but the number of possible ardennite-group minerals is restricted for both geochemi$\mathrm{cal}$ and crystal-chemical reasons. With the ionic radii of $\mathrm{As}^{5+}$ and $\mathrm{V}^{5+}$ being the most similar of the cations occupying the $T 4$ site, one can suppose a geochemical cause for the absence of the As-V solid solution.

A slight deviation from the proposed formula calculation procedure has been applied to the analysis of ardennite(As) from Nežilovo. The approach used in earlier papers would exceed the possible $\mathrm{OH}$ content of ardennite structure, and the procedure proposed by Nagashima and Armbruster (2010) would imply vacancies in the anionic sites which were not detected. Therefore, a compromise between achieving electroneutrality and satisfying the occupancy of the anionic sites was made by introducing minor substitution of $\mathrm{OH}$ for $\mathrm{H}_{2} \mathrm{O}$ in ardennite.

Based on the evidence from micas and peculiar mineralogy of the Nežilovo occurrence, three stages of deposit evolution are proposed. Stage 1 occurred in the Precambrian and includes sedimentation of chemically very diverse sediments which had a significant role in the formation of unusual mineral associations. These sediments experienced a high-grade, high-pressure metamorphic event in Stage 2 that is most evident in an area between the Pelagonian Massif and the Vardar zone. The decrease in temperature due to upwards geotectonic movement, Stage 3, took place marked by retrograde metamorphism. Ardennite-(As) formed in the third stage, under the low-grade metamorphic conditions matching greenschist facies.

Further research is needed to explain the connection between this and other mineral associations of the Nežilovo locality in North Macedonia. This unique locality contains very complex mineral parageneses of rare silicates and nonsilicates.

Data availability. All data derived from this research are available upon request from the corresponding author.

Author contributions. VB and VZ recognized and provided the study materials. VZ was in charge of sample separation for further analyses. MB and VB were in charge of the conceptualization. BS performed optical studies of the materials, and his notes were of crucial value to the manuscript. VB conducted the X-ray experiments of the materials. IB prepared and created the geological map of North Macedonia and provided financial support for the project. 
NVC contributed to the Introduction and Discussion sections. MB was in charge of original draft preparation and the review and editing process.

Competing interests. The authors declare that they have no conflict of interest.

Disclaimer. Publisher's note: Copernicus Publications remains neutral with regard to jurisdictional claims in published maps and institutional affiliations.

Acknowledgements. The authors are fully thankful to Franz Brandtstätter and Malcolm Back for providing EMPA of ardennite and mica, respectively. A part of the materials used for this study were from the master's thesis of Davor Kudrnovski who was mentored by Vladimir Bermanec. The contribution of Nikita V. Chukanov was made in accordance with the state task, state registration no. AAAA-A19-119092390076-7. The authors also appreciate the suggestions of Marco Pasero and Anthony Kampf during the initial preparation of the manuscript. Simeon Jančev deserves special gratitude from the authors for helping them conduct the fieldwork.

Masahide Akasaka and the anonymous reviewer are acknowledged for providing comments that significantly improved the quality of the manuscript, especially for encouraging the expansion of the discussion on the structural formula calculation.

Review statement. This paper was edited by Joaquin A. Proenza and reviewed by Masahide Akasaka and one anonymous referee.

\section{References}

Allmann, R. and Donnay, G.: Structural Relations between Pumpellyite and Ardennite, Acta Cryst., 27, 1871-1875, https://doi.org/10.1107/S0567740871005016, 1971.

Altherr, R., Soder, C., Meyer, H. - P., Ludwig, T., and Böhm, M.: Ardennite in high - P/T meta - conglomerate near Vitolište in the westernmost Vardar zone, Republic of Macedonia, Eur. J. Mineral., 29, 473-489, https://doi.org/10.1127/ejm/2017/0029-2610, 2017.

Armbruster, T., Bermanec, V., Zebec, V., and Oberhaensli, R.: Titanium and iron poor zincohoegbomite-16H, Zn14(Al, Fe3+, Ti, $\mathrm{Mg}) 8 \mathrm{Al} 24 \mathrm{O} 62(\mathrm{OH}) 2$, from Nežilovo, Macedonia: occurrence and crystal structure of a new polysome, Schweiz. Miner. Petrog., 78, 469-477, 1998.

Arsovski, M. and Dumurdzanov N.: Recent findings of the structure of the Pelagonian antidinorium and its relation with the Rhodopean and Serbian Macedonian Massif, Geologica Macedonica, 2, 15-22, 1984.

Bailey, S. W.: Micas, Reviews in Mineralogy, Vol 13, edited by: Ribbe, P. H., Mineralogical Society of America, Madison, Wisconsin, USA, 1984.
Barić, Lj.: Piemontit, gahnit und rutil aus dem Fundort der Blei und Zinkerze bei dem Dorfe Nezilovo in Mazedonien, Glasnik Prirodnjačkog Muzeja, Beograd Ser. A., 13, 200-204, 1960.

Barić, Lj. and Ivanov, T.: Mineralvergesellschaftung in der Umgebung des Dorfes Nežilovo am Jakupica-Gebirge in Mazedonien, Bull. Sci. A Zagreb, 5, p. 2, 1960.

Barresi, A., Orlandi, P., and Pasero, M.: History of ardennite and the new mineral ardennite-(V), Eur. J. Mineral., 19, 581-587, https://doi.org/10.1127/0935-1221/2007/0019-1745, 2007.

Bence, A. E. and Albee, A. L.: Empirical correction factors for the electron microanalysis of silicates and oxides, J. Geol., 76, 382403, 1968.

Bermanec, V.: Kristalokemijske karakteristike minerala iz asocijacija koje sadrže barijske silikate, $\mathrm{PhD}$ thesis, University of $\mathrm{Za}$ greb, Croatia, 1992.

Bermanec, V., Armbruster, T., and Oberhänsli, R.: Crystal chemistry of $\mathrm{Pb}$ - and REE-rich piemontite from Nezilovo, Macedonia, Schweiz. Miner. Petrog., 74, 321-328, 1994.

Bermanec, V., Holtstam, D., Sturman, D., Criddle, A. J., Back, M. E., and Scavnicar, S.: Nežilovite, a new member of the magnetoplumbite group, and the crystal chemistry of magnetoplumbite and hibonite, Can. Mineral., 34, 1287-1297, 1996.

Bloss, F. D.: The spindle stage: principles and practice, Cambridge and New York, Cambridge University Press, 1981.

Chimenti, S.: Studio cristallochimico di campioni di ardennite di località italiane ed estere, $\mathrm{PhD}$ thesis, University of Pisa, Italy, 2004.

Chukanov, N. V.: Infrared spectra of mineral species: Extended library. Springer-Verlag GmbH, Dordrecht-HeidelbergNew York-London, https://doi.org/10.1007/978-94-007-7128-4, 2014.

Chukanov, N. V., Varlamov, D. A., Nestola, F., Belakovskiy, D. I., Goettlicher, J., Britvin, S. N., Lanza, A., and Jancev, S.: Piemontite- $(\mathrm{Pb}), \mathrm{CaPbAl}_{2} \mathrm{Mn}^{3+}\left[\mathrm{Si}_{2} \mathrm{O}_{7}\right]\left[\mathrm{SiO}_{4}\right] \mathrm{O}(\mathrm{OH})$, a new mineral species of the epidote supergroup, Neues. Jb. Miner. Abh., 189, 275-286, https://doi.org/10.1127/00777757/2012/0224, 2012.

Chukanov, N. V., Jančev, S., and Pekov, I. V.: The association of oxygen-bearing minerals of chalcophile elements in the orogenetic zone related to the "mixed series" complex near Nežilovo, Republic of Macedonia, Maced. J. Chem. Chem. En., 34, 115124, https://doi.org/10.20450/mjcce.2015.612, 2015.

Chukanov, N. V., Aksenov, S. M., Jančev, S., Pekov, I. V., Göttlicher, J., Polekhovsky, Yu. S., Rusakov, V. S., Nelyubina, Y. V., and Van, K. V.: A new mineral species ferricoronadite, $\mathrm{Pb}\left[\mathrm{Mn}_{6}^{4+}\left(\mathrm{Fe}^{3+}, \mathrm{Mn}^{3+}\right)_{2}\right] \mathrm{O}_{16}:$ mineralogical characterization, crystal chemistry and physical properties, Phys. Chem. Miner., 43, 503-514, https://doi.org/10.1007/s00269-016-0811z, 2016.

Chukanov, N. V., Zubkova, N. V., Schäfer, C., Varlamov, D. A., Ermolaeva, V. N., Polekhovsky, Yu. S., Jančev, S., Pekov, I. V., and Pushcharovsky, D. Yu.: New data on ferriakasakaite(La) and related minerals extending the compositional field of the epidote supergroup, Eur. J. Mineral., 30, 323-332, https://doi.org/10.1127/ejm/2018/0030-2716, 2018 a.

Chukanov, N. V., Krzhizhanovskaya, M. G., Jančev, S., Pekov, I. V., Varlamov, D. A., Göttlicher, J., Rusakov, V. S., Polekhovsky, Yu. S., Chervonnyi, A. D., and Ermolaeva, V. N.: Zincovelesite-6N6S, $\mathrm{Zn}_{3}\left(\mathrm{Fe}^{3+}, \mathrm{Mn}^{3+}, \mathrm{Al}, \mathrm{Ti}\right)_{8} \mathrm{O}_{15}(\mathrm{OH})$, 
a new högbomite-supergroup mineral from Jacupica mountains, Republic of Macedonia, Miner. Petrol., 112, 733-742, https://doi.org/10.1007/s00710-018-0555-1, 2018b.

Chukanov, N. V., Vorobei, S. S., Ermolaeva, V. N., Varlamov, D. A., Plechov, P. Y., Jančev S., and Bovkun, A. V.: New data on chemical composition and vibrational spectra of magnetoplumbite-group minerals, Geol. Ore Deposits, 61, 637646, https://doi.org/10.1134/S1075701519070055, 2019.

Chukanov, N. V., Zubkova, N. V., Jančev, S., Pekov, I. V., Ermolaeva, V. N., Varlamov, D. A., Belakovskiy, D. I., and Britvin, S. N.: Zinc - rich and copper - bearing amphiboles from sulfide - free ore occurences of the Pelagonian Massif, Republic of North Macedonia, Miner. Petrol., 114, 129-140, https://doi.org/10.1007/s00710-020-00694-z, 2020a.

Chukanov, N. V., Varlamov, D. A., Ermolaeva, V. N., and Jančev, S.: The role of barium in the formation of sulfidefree ores with chalcophile elements in the "Mixed Series" of the Pelagonian massif, Zapiski Rossiiskogo Mineral. Obshchestva (Proc. Rus. Mineral. Soc.), 149, 96-107, https://doi.org/10.31857/S0869605520010116, 2020b (in Russian).

Coombs, D. S., Kawachi, Y., and Reay, A.: An Occurrence of Ardennite in Quartz Veins in Piemontite Schist, Western Otago, New Zealand, Miner. Petrol., 48, 295-308, https://doi.org/10.1007/BF01163105, 1993.

Donnay, G. and Allmann, R.: $\mathrm{Si}_{3} \mathrm{O}_{10}$ Groups in the Crystal Structure of Ardennite, Acta Crystallogr. B, 24, 845-855, https://doi.org/10.1107/S0567740868003274, 1968.

Ermolaeva, V. N., Chukanov, N. V., Jančev, S., and Van, K.: Endogenic oxide parageneses with chalcophile elements in the orogenetic zone related to the "Mixed Series" of the Pelagonian massif, Republic of Macedonia, New Data on Minerals, 51, 12-19, 2016.

Ermolaeva, V. N., Chukanov, N. V., Jančev, S., and Van, K. V.: Parageneses of Oxygen-bearing Minerals with Chalcophile Elements in Metasomatites of the Pelagonian Massif Macedonia, Magmatism of the Earth and related strategic metal deposits, 62-66, 2017.

Ermolaeva, V. N., Varlamov, D. A., Jančev, S., and Chukanov, N. V.: Spinel- and högbomite-supergroup minerals from sulfide-free endogenic $\mathrm{Pb}-\mathrm{Zn}-\mathrm{Sb}-\mathrm{As}$ assemblage in Pelagonian Massif, Republic of North Macedonia, Geol. Ore Deposits, 61, 628-636, https://doi.org/10.1134/S1075701519070067, 2019a.

Ermolaeva, V. N., Varlamov, D. A., Chukanov, N. V., and Jančev, S.: Forms of arsenic concentration in sulfide-free endogenic $\mathrm{Pb}-\mathrm{Zn}-\mathrm{Sb}$ ores of the Pelagonian massif, Republic of North Macedonia, Geol. Ore Deposits, 61, 782-790, https://doi.org/10.1134/S1075701519080038, 2019 b.

Frost, R. L., López, A., Xi, Y., Scholz, R., and Gandini, A. L.: A vibrational spectroscopy study of the silicate mineral ardennite - (As), Spectrochim. Acta A, 118, 987-991, https://doi.org/10.1016/j.saa.2013.09.148, 2014.

Holtstam, D. and Langhof, J. (Eds.): Långban: The mines, their minerals, geology and explorers, Raster Förlag, Stockholm, 1999.

Ivanov, T. and Jančev, S.: "Nežilovo" - a complex polimetallic deposit of "Franklin Furnace" type in Macedonia, Proceedings of the Yugoslavian Geological Congress 5, Ljubljana, 69-78, 1976.
Jančev, S.: The occurrence of cymrite at the village of Nežilovo in Macedonia, Bull. Sci. A Zagreb, 20, 9-10, 1975.

Jančev, S.: Discussion about the zonal development of the "mixed series" of the Pelagonian massif in the upper part of the Babuna river - Macedonia, Proceedings of the Yugoslavian Geological Congress IX, 333-340, 1978.

Jančev, S.: Zn-rich pyroxenes from the occurrences in the mixed series in the upper part of the Babuna River, Macedonia, Geologija (Ljubljana), 40, 283-289, https://doi.org/10.5474/geologija.1997.013, 1998.

Jančev, S. and Chukanov, N. V.: Short review of some rare minerals from a "mixed series" in the pre-Cambrian complex near Nezilovo village, Macedonia, Working Papers of the 1st Macedonian Geological Congress, Ohrid, Macedonia, October 2008, Ohrid, 291-299, 2008.

Jančev, S., Chukanov, N. V., and Ermolaeva, V. N.: Association of oxide minerals - concentrators of chalcophile elements $(\mathrm{Pb}, \mathrm{Zn}$, $\mathrm{Sb}$ ) from the "Mixed series" near Nežilovo village, Macedonia. Materials of the Third Congress of Geologists of Republic of Macedonia, Struga, 30 September-2 October 2016, 2, 401-404, 2016.

Kampf, A. R., Carbone, C., Belmonte, D., Nash, B. P., Chiappino, L., and Castellaro, F.: Alpeite, $\mathrm{CaMn}_{2}^{3+} \mathrm{Al}_{2}\left(\mathrm{Mn}^{3+} \mathrm{Mg}\right)\left(\mathrm{SiO}_{4}\right)_{2}\left(\mathrm{Si}_{3} \mathrm{O}_{10}\right)\left(\mathrm{V}^{5+} \mathrm{O}_{4}\right)(\mathrm{OH})_{6}, \quad$ a new ardennite-group mineral from Italy, Eur. J. Mineral., 29, 907-914, https://doi.org/10.1127/ejm/2017/0029-2636, 2017.

Kamzolkin, V. A., Ivanov, S. D., and Konilov, A. N.: Empirical phengite geobarometer: Background, calibration, and application, Geol. Ore Deposits, 58, 613-622, https://doi.org/10.1134/S1075701516080092, 2016.

Kudrnovski, D.: Kristalokemija tinjaca iz metamorfnog kompleksa u blizini sela Nežilovo, Makedonija, MS thesis, University of Zagreb, Croatia, 1997.

Lindquist, O. and Wengelin, F.: Powder, a program for the refinement of cell dimensions and for the indexing of powder photographs, Ark. Kemi., Gothenburg, 28, 197 pp., 1967.

Majer, V. and Mason, R.: High - pressure metamorphism between the Pelagonian Massif and Vardar Ophiolite Belt, Yugoslavia, Mineral. Mag., 47, 139-141, https://doi.org/10.1180/minmag.1983.047.343.03, 1983.

Matsubara, S. and Kato, A.: Ardennite from Sanbagawa in Sanbagawa metamorphic terrain, Kanto Mountains, Japan, Bull. Natn. Sci. Mus. Ser. C, 13, 1-11, 1987.

Moore, P. B.: Cell data of orientate and its relation to ardennite and zoisite, Can. Mineral., 8, 262-265, 1965.

Most, T.: Geodynamic evolution of the Eastern Pelagonian Zone in northwestern Greece and the Republic of Macedonia, Implications from U/Pb, $\mathrm{Rb} / \mathrm{Sr}, \mathrm{K} / \mathrm{Ar},{ }^{40} \mathrm{Ar} /{ }^{39} \mathrm{Ar}$ geochronology and fission track thermochronology, $\mathrm{PhD}$ thesis, Geowissenschaftlichen Fakultät der Eberhardt-Karls-Universität, Tübingen, 2003.

Mountrakis, D.: Structural evolution of the Pelagonian Zone in Northwestern Macedonia, Greece, Geol. Soc. Spec. Publ., London, 17, 581-590, https://doi.org/10.1144/GSL.SP.1984.017.01.45, 1984.

Nagashima, M. and Armbruster, T.: Ardennite, tiragalloite and mediate: structural control of $\left(\mathrm{As}^{5+}, \mathrm{V}^{5+}, \mathrm{Si}^{4+}\right) \mathrm{O}_{4}$ tetrahedra in silicates, Mineral. Mag., 74, 55-71, 2010. 
Nayak, V. K.: Ardennite from Kajlidongri, India: a new locality, Neues Jb. Miner. Monat., 9-10, 295-303, 1967.

Nishio-Hamane, D., Nagashima. M., Ogawa, N., and Minakawa, T.: Kannanite, a new mineral from Kannan Mountain, Japan, J. Miner. Petrol. Sci., 113, 245-250, https://doi.org/10.2465/jmps.180103, 2018.

Orlandi, P., Biagioni, C., Pasero, M., and Mellini, M.: Lavoisierite, $\quad \mathrm{Mn}_{8}^{2+}\left[\mathrm{Al}_{10}\left(\mathrm{Mn}^{3+} \mathrm{Mg}\right)\right]\left[\mathrm{Si}_{11} \mathrm{P}\right] \mathrm{O}_{44}(\mathrm{OH})_{12}, \quad$ a new mineral from Piedmont, Italy: the link between "ardennite" and sursassite, Phys. Chem. Miner., 40, 239-249, https://doi.org/10.1007/s00269-013-0564-x, 2013.

Pasero, M. and Reinecke, T.: Crystal chemistry, HRTEM analysis, and polytypic behavior of ardennite, Eur. J. Mineral., 3, 819-830, https://doi.org/10.1127/ejm/3/5/0819, 1991.

Pasero, M., Reinecke, T., and Fransolet, A.-M.: Crystal structure refinements and compositional control of $\mathrm{Mn}-\mathrm{Mg}-\mathrm{Ca}$ ardennites from the Belgian Ardennes, Greece and the Western Alps, Neues Jb. Miner. Abh., 166, 137-167, 1994.

Pisani, F.: Analyse de la dewalquite de Salm-Château en Belgique, Cr. Acad. Sci. II A, 77, 329-333, 1873.

Reinecke, T. and Hatzipanagiotou, K.: Crystal chemistry and lattice parameters of ardennites from Andros Island, Greece, and Haute - Maurienne, Western Alps, Neues Jb. Miner. Abh., 158, 189204, 1987

Sassi, F. P., Guidotti, C. V., Rieder, M., and De Pieri, R.: On the occurrence of metamorphic $2 M_{1}$ phengites: some thoughts on polytipism and crystallization conditions of $3 T$ phengites, Eur. J. Mineral., 6, 151-160, https://doi.org/10.1127/ejm/6/1/0151, 1994.

Semet, M. and Moreau, J.: L'ardennite: revision et données nouvelles, Annales Soc. Géol. Belg., 88, 545-577, 1965.
Shannon, R. D. and Prewitt, C. T.: Effective ionic radii in oxides and fluorides, Acta Cryst. B, 25, 925-946, https://doi.org/10.1107/S0567740869003220, 1969.

Stojanov, P.: Prethodni rezultati od geološkite i petrografskite istražuvanja na visokometamorfnite steni vo centralniot del na Pelagonskiot masiv, Trudovi na geološkiot zavod na Narodna Republika Makedonija, 7, 147-180, 1960.

Stojanov, R.: Phengites of the Pelagonian massif, Trudovi na Geoloskiot Zavod na Socijalisticka Republika Makedonija, 13, 5973, 1967-1968.

Strunz, H.: Structurelle und morphologische Beziehungen zwischen Epidot und Zoisit und Zwischen Epidot und Ardennit, Z. Kristallogr., 92, 402-407, https://doi.org/10.1524/zkri.1935.92.1.402, 1935.

Varlamov, D. A., Ermolaeva, V. N., Jančev, S., and Chukanov, N. V.: Oxides of the pyrochlore supergroup from a nonsulfide endogenic assemblage of $\mathrm{Pb}-\mathrm{Zn}-\mathrm{Sb}-\mathrm{As}$ minerals in the Pelagonian massif, Macedonia, Geol. Ore Deposits, 60, 717-725, https://doi.org/10.1134/S107570151808010X, 2018.

von Lasaulx, A.: Über ein neues Mineral aus der Gegend von Ottrez. Verh. Naturh, Ver. preuss. Rheinl. Westph., 29, p. 189, 1872.

von Walter, F., Auer, C., Bojar, H.-P., Friebe, G., Jakely, D., Kolitsch, U., Kiseljak, R., Knobloch, G., Leikauf, B., Lóránth C., Löffler, E., Mäser, R., Postl, W., Putz, H., Rausch, L., Schachinger, T., Schillhammer, H., Slama, M., Steck, C., and Weiss, J.: Neue Mineralfunde aus Österreich LXVII, Carinthia II, 208/128, 185-254, 2018.

Yoder, H. S. and Eugster, H. P.: Synthetic and natural muscovites, Geochim. Cosmochim. Ac., 3, 225-280, 1955. 